\section{Daisy e Dionísia: três peças com \\ o teatro de poetas de Pessoa}

ARMANDO NASCIMENTO ROSA

Between 2002 and 2013, the author of this article published and saw staged three different plays that establish creative dialogues with the work of Fernando Pessoa. Two of them - Audição - Com Daisy ao vivo no Odre Marítimo (Audition - With Daisy live in Lisbon) and Cabaré de Ofélia (Ophelia's Cabaret) constitute a dramaturgical diptych sharing a common character who is present in both: Daisy Mason; reinvention of the figure from a Pessoa's poem, portrayed in them as a drag-queen friend of Álvaro de Campos, "legend of poetry and music-hall". The third of these plays, Menino de sua Avó (Fernando and his Grandmother), brings to the theatrical scene Dionísia Seabra, Fernando's crazy grandmother, in a play with seven scenic encounters between grandmother and grandson that extend beyond the physical death of both. The article begins by establishing a brief comprehensive picture of Pessoa's approach to the universe of theater and dramatic creation, namely that which in its plural creation is identified with a function that we can designate as a poet-actor. The discursive course of the article gives attention to each of the mentioned plays, articulating the motivations for their writing, the imaginary that constitutes them, as well as the way they relate to elements and figures from the fictional universe of Fernando Pessoa.

THEATRE / FERNANDO PESSOA / POET-ACTOR / DRAMATURGICAL CREATION / TEXT AND SCENE

A literatura é a expressão verbal de um temperamento; a literatura narrativa, a forma objectiva dessa expressão verbal; a literatura dramática a forma sintética dessa expressão objectiva. Um drama não é mais que um romance na sua forma máxima de síntese possivel. FERNANDO PESSOA [BNP/E3, 141-2Or e 20ar; ver Anexo]

Fernando Pessoa, mago dos paradoxos, também nos escritos que destinou para o teatro (ou que o teatro viria a adoptar como seus) manifesta essa travessia que mescla géneros, regimes de expressão, reinventando-os pela subversão que transcende a definição convencional de cada um deles, e que lhes conferia uma ilusão de estabilidade genológica. Não é por isso de estranhar que a dramaturgia mais revolucionária de Pessoa esteja alojada na metateatralidade do drama-em-gente e que, no jogo que esta traça, seja Álvaro de Campos o dramaturgo fulgurante por excelência que se põe em cena num monólogo intérmino, personagem que prescinde de peça, um novo Hamlet para o século xx; por isso livre já de um enredo teatral que o comprima em qualquer Elsinore, uma vez que para prisão - uma «prisão-teatro», como lhe chamou Teresa Rita Lopes (Lopes, 2004: 336) - basta a Campos a condição vivente que todos os humanos com ele partilham de «escravos cardíacos das estrelas» (Pessoa, 2019: 214).

E este ascendente shakespeariano em Pessoa, que situa a despersonalização dramática no fulcro da sua criação poética - traduzido pela «forma maximamente objectiva» no excerto em epígrafe (oriundo de anotação que eu antes lera numa primeira transcrição parcial publicada por Maria Aliete Galhoz - Pessoa, 1981: 601) -, acompanha mais além ainda o bardo teatral inglês eleito, desde o romantismo, para ocupar o centro do cânone literário da Idade Moderna. Por este mais além, entendo uma dimensão metafórica que aponta, num gesto cénico, para lá do literário propriamente dito, conforme passo a elucidar. Não é de admirar que Harold Bloom - geógrafo de cânones literários, apaixonado exegeta de Shakespeare e teorizador dessa revisão psicanalítica da emulatio greco-latina a que chamou «anxiety of influence» - tivesse sido tocado tão intensamente pelo caso Pessoa. Mas estou em crer que o duelo de influências jogado por Pessoa face ao ascendente Shakespeare tenha induzido o poeta português a medir forças além do literário, mesmo que esse duelo se tivesse manifestado concretamente em literatura. Poeta dramático, assim quis Pessoa ser cognominado, mas o seu drama-em-gente aproxima-o, enquanto criador literário, da outra arte que o dramaturgo Shakespeare também exerceu (mesmo que, segundo consta, nela não tenha atingido a excelência que a dramaturgia lhe reservaria nos palcos isabelinos): a profissão de actor. De facto, a invenção dos heterónimos com suas obras diferenciadas faz de Pessoa uma espécie singular de poeta-actor; um actor que representa, não através de papéis no tablado, mas antes por intermédio da criação de personalidades fictícias transformadas em autores. Nesta perspectiva, a resolução da bloomiana ansiedade da influência, diagnosticada em Pessoa para com Shakespeare, operar-se-ia assim em duas vertentes, que se geminam entre si, e graças às quais Pessoa ambicionou superar o autor de 
Hamlet: por um lado, em vez de compor prioritariamente peças com personagens, destinadas a ser vividas pela pele de actores, dentro daquilo que se convencionou ser a arte do dramaturgo, Pessoa inventa uma metadramaturgia na qual diversos autores literários contracenam por meio das suas obras e das suas personalidades, numa performatividade virtual que não cabe já nas fronteiras delimitadas de um espectáculo ou de uma simples peça de teatro escrito; por outro lado, o modo como ele inventa o seu drama-em-gente manifesta uma forte analogia para com o processo de criação de personagem próprio dos actores, a partir do momento em que forja vidas autónomas para os autores fictícios nos quais literariamente se mascara e metamorfoseia, com corpos e personalidades que a imaginação congemina e encena, mas que não se confinam já às fronteiras estanques de um livro ou de uma peça teatral. Pessoa é então esse poeta-actor que inventa e orquestra um teatro de poetas, pleno de possibilidades plurais de se ver jogado. E este jogo é válido mesmo quando ele assina os textos ortónimos, animado que está pelo desassossego vivaz de uma influência ansiosa, explicitada na pulsão de autor-actor que o leva a encarnar os papéis de outros escritores; visto que, como escreve Jerónimo Pizarro num ensaio assaz pertinente para o ponto de vista que me move (e que eu aqui traduzo do original em espanhol), «quando se diz Pessoa, fala-se sempre no plural, pois Pessoa, na sua qualidade de autor das obras ortónimas, foi o autor de obras tão diferentes como Fausto, O Marinheiro, 35 Sonnets, e Mensagem, o tetráptico com o qual Pessoa quis ser Goethe, Maeterlinck, Shakespeare e Camões» (Pizarro, 2017: 478).

Alinhavar em forma escrita motivações que nos levam a escrever determinada obra ficcional é também uma outra forma de ficcionar. Ainda assim, irei render-me uma vez mais (como já o fiz à guisa de prefácios ou posfácios a estas peças, aos quais fui agora pilhar alguns fraseados), nestas breves considerações, à tentativa de reunir alinhavos em torno das obras dramáticas que escrevi até à data nas quais Fernando Pessoa - por via do seu universo criacional - se constituiu como figura motriz e matriz, de formas diversas em cada uma delas. Sendo três peças com temáticas pessoanas, elas não estabelecem uma trilogia; melhor dizendo, duas delas formam um díptico em diálogo e interacção mútuos (Audição-Com Daisy ao vivo no Odre Marítimo e Cabaré de Ofélia), e uma terceira posiciona-se num outro regime de concepção cénica e dramatúrgica (Menino de sua Avó).

\section{AUDIÇÃO - COM DAISY AO VIVO NO ODRE MARÍTIMO}

A evidência de entender Fernando Pessoa como um escritor que se comporta à maneira dos actores na sua criação poética terá sido o primeiro impulso para a composição da mais antiga destas três peças de que aqui dou testemunho, num gesto que junta o fingimento teatral pessoano que inventava escritores inexistentes também para se sentir acompanhado e «compreendido»-à experiência do actor que, paradoxalmente, não desiste perante a ausência radical de olhos que observem a sua arte: Audição - Com Daisy ao vivo no Odre Marítimo (escrita em 1998, revista e editada em livro em Novembro de 2002 para se estrear em Fevereiro do ano seguinte, no Teatro Maria Matos; produção da Cassefaz encenada por Élvio Camacho, com Jorge Andrade no papel de actor-candidato e Filipe Raposo ao piano). Uma junção que se materializa no cruzamento que a peça opera entre a mundividência de um actor na solidão do espaço cénico e o teatro de poetas pessoano, num jogo cabarético e musical em que uma inesperada Daisy (ou nem tanto) de «Soneto já antigo» - por surgir numa pele de drag-queen - se torna mestra-de-cerimónias, convidando-nos a uma incursão multímoda pela desassossegada psique do seu íntimo amigo Álvaro de Campos. Eugénia Vasques, na sessão pública de apresentação da primeira edição da peça em livro, na Casa Fernando Pessoa, em 12 de Dezembro de 2002, falava mesmo de «um tratamento de choque a Álvaro de Campos», perpetrado pelo autor destas linhas no texto dramático em questão. Mas antes de comentar o inerente a esta afirmação memorável, de cognitiva diversão, importa traçar um esboço mínimo referente à anatomia da peça, onde vejo residir a sua bicéfala identidade dramatúrgica, sob o signo de Daisy Mason; enigmática figura pessoana de quem nada mais sabemos a não ser o que Pessoa coloca no célebre soneto de Campos que lhe é dedicado e que a interpela, bem como ainda uma menção ao seu nome no verso deste heterónimo que abre um fragmento de 1927: «A vida é para os inconscientes (ó Lídia, Celimène, Daisy)» (Pessoa, 2019: 211).

Audição - Com Daisy ao vivo no Odre Marítimo é uma peça dupla que integra duas realidades teatrais em si mesma; ou melhor, há uma peça que está contida numa outra, e que a informação inscrita no título denuncia: temos a fala prolixa de um actor, que veio fazer uma audição e é confrontado com a solidão da cena, num teatro vazio, sem júri para o avaliar nem outros candidatos a comparecer; e temos o conteúdo da audição propriamente dita, que ele representa nessa sala, como se houvesse 
público a assistir, e que consiste no show ao vivo de Daisy Mason Waterfields (este segundo apelido é um náutico baptismo que lhe dei), «lenda viva da poesia e do music-hall» (Rosa, 2002: 28), actuando no espaço imaginário do Odre Marítimo, navio que cruza o Tejo, consagrado ao espectáculo contínuo das artes e cujo patrono é Álvaro de Campos - quem sabe materializando esse tal «Cabaret de Lisboa» pelo qual Campos se interroga num verso seu de poema sem título, datado de 1932 (Pessoa, 2019: 293).

É nesta segunda realidade cénica, que corresponde ao show de Daisy, que a presença pessoana irrompe na peça de forma decisiva; antes disso, regista-se o indício semeado pelo poema ortónimo que tornei tema de cante alentejano estilizado - «Um cantar velado e lento» - trauteado pelo actor-candidato, que adiante anunciará a sua imersão teatral no cosmo de Pessoa, quando resolve enfim abandonar a torrente discursiva e errática de alguém que fala para ninguém, como se estivesse a improvisar para preencher o silêncio (e por isso esta primeira parte da peça é dramaturgicamente passivel de muitas versões de maior ou menor abreviação textual possível na abordagem cénica, como já sucedeu em diferentes produções dela), e decide abraçar o jogo de ser outro com o número que ensaiou em casa para a audição a que se propõe. Se Pessoa gerou pela proliferação heteronímica - como ele próprio o prescreveu toda uma literatura a haver, o actor-candidato de Audição deseja reinventar um teatro que não há, ou seja, um teatro que ele não encontrou ao aportar naquele espaço cénico desértico.

ACTOR-CANDIDATO Não, eu não me vou dar tão depressa por vencido. Trago um número preparado e vou representá-lo, nem que seja só para me inflamar o ego. Estava com medo ao princípio e não quis confessá-lo; mas desde que li o anúncio, há três semanas, não tenho feito outra coisa senão ensaiar frente ao espelho uma série de cenas inventadas por mim. Nem tenho quase posto os pés na rua. Meti atestado médico no café onde estou empregado, o Maldita Cafeína. É dali que me vem o sustento... Por enquanto... Até que apareça coisa séria para mim num sítio como este. [...] Tive tempo para pensar em tudo. Podiam estar a querer alguém para digressões ao estrangeiro, e eu trouxe a referência portuguesa mais famosa no universo, a seguir ao fado, aos futebóis, e ao vinho do Porto: o nosso querido Fernando Pessoa. Depois, lembrei-me de mostrar toda a minha versatilidade, a abertura de espírito - e de corpo - exigida a um ator...
E pronto, de introdução já basta. Suba o pano que o show vai começar! (Rosa, 2013: 31)

E é neste preciso momento que o actor-candidato se prepara para regressar à cena transformado na personagem de Daisy, a amiga escocesa do pansexual Campos, num travesti no qual, antes de tudo o resto que possamos nele ler de trânsito provocatório entre géneros, se aloja a reiteração do fenómeno teatral como lugar onde a alteridade conquista uma cidadania, inscrita já nas suas origens helénicas, no contexto cultual tutelado pelo andrógino deus Dioniso, como único reduto onde se tornava possível aplaudir publicamente a céu aberto o que noutro lugar seria ostracizado pela pólis androcrática. E esta herança civilizacional que a arte teatral comporta, sublinho, liga-se fortemente ao elemento mais revolucionário da obra de Pessoa, naquilo que ele designou como missão maior para si: a de indisciplinador de almas. Natália Correia, num ensaio seu de densa brevidade que fez editar em 1958 (Poesia de Arte e Realismo Poético), comenta nestes termos a potencialidade liberadora e plural da obra pessoana - e é curioso podermos subentender neste «convite à negação», de que fala Natália, a afirmação de filiação inevitável em Pessoa daqueles presencistas que à época, como José Régio e Miguel Torga, usavam de gestos edipianos para desferir sobre esse titânico Laio do modernismo que os assombrava em ansiedade da influência:

A linha fecunda que parte dos poetas libertadores no número dos quais Fernando Pessoa se inclui é o convite à negação da sua obra na medida em que ela é já um valor conquistado. A única possível filiação que o poeta oferece aos continuadores do seu espírito é o incitamento à experiência concreta de cada um. (Correia, 1958: 22-23)

Pode entender-se como tributo dramático que presto a esse espírito incitador o fazer de Daisy Mason uma criatura corajosa e emancipatória, desafiadora das convenções de género num tempo histórico precoce, que se finge de mulher fatal em corpo masculino, que vem para Lisboa nos anos 1910 - curiosamente ao tempo em que o sexólogo pioneiro Magnus Hirschfeld cunhava na Alemanha o termo travesti (Wolff, 1986: 107) -, trazida pelo engenheiro naval e por cá faz vida de artista; chegando até a ser alvo de uma arrebatada declaração de amor por parte de um Pessoa bem bebido, em pleno café A Brasileira, num episódio cénico repleto de humor, após Daisy desmontar com garra e com brilho 
a argumentação de um Campos que desaprova duramente a hipótese de Fernando se casar com Ofélia. O triálogo entre Daisy, Pessoa e Campos acentua o quanto Audição, nesta sua segunda jornada dramatúrgica, se afasta da estrutura monologante e, se bem que um só actor se possa desdobrar para as falas destes três, a diversidade das experiências cénicas tem demonstrado que parcerias entre um actor-candidato e uma actriz-cantora (como aconteceu na produção de estreia, com Inês Nogueira) ou um actor-candidato e um pianista-actor, que acompanha musicalmente os momentos cantados e interpreta figuras como Álvaro de Campos e o Apresentador do Odre Marítimo, dando tempo a que, por exemplo, o actor se mude para o visual de Daisy (como foi o caso da encenação de José Maria Dias, no Teatro Estúdio Fontenova, em Setúbal, com Eduardo Dias e Bruno Moraes, em cena entre 2004 e 2010), podem bem ser as fórmulas mínimas mais praticáveis para a realização da peça (enquanto não surgir um actor para Daisy que seja pianista e se acompanhe a si mesmo nas canções que inseri no guião, e talvez nesse caso a contracena possa acontecer somente com trechos em projecção virtual, quando tal se afigure imprescindível).

DAISY [...] O Álvaro não abriu a boca, despeitado, mas o Fernando fascinara-se com as minhas palavras. Elogiou-me a beleza e perguntou-me se eu era solteira. Foi então que ele perdeu a cabeça e declarou-se-me com olhos de bagaço:

FERNANDO PESSOA Se fosse para me casar consigo, Daisy, eu já não teria dúvidas. Você seria a musa que falta à minha poesia, a Beatriz que nem o Dante teve. Juntos seríamos maiores que o casal Shelley. Case-se comigo, Daisy, case-se comigo! Tudo se conjuga para a intersecção dos nossos destinos: eu sou um português de educação inglesa, você é uma britânica lusómana. Da nossa aliança, eu avisto o quinto império...

DAISY A Brasileira toda estava presa pela minha resposta. Por momentos receei que o Álvaro, com a cara carrancuda, revelasse grosseiramente a impossibilidade de tal casamento. Fui frouxa, não lhe respondi à pergunta, apenas Ihe desejei felicidades para ele e para a Ofélia que eu não conhecia. Saí bruscamente do café com a desculpa de uma prova na costureira.

O maior poeta do século xx tinha-me pedido em casamento e em nenhum outro momento da minha vida eu lamentei tanto o facto de não ter nascido com uma vagina entre as pernas. [...] (Rosa, 2002: 35-36)
E será Daisy uma espécie de novo heterónimo que ousei moldar em teatro para juntar à antologia das criaturas fictícias de Pessoa, dando uma vida trans à Daisy Mason do soneto de Campos? Foi uma pergunta que vários espectadores atentos me foram fazendo, ao assistir aos espectáculos das quatro diferentes produções cénicas de que a peça foi alvo desde 2003. De facto, o episódio cénico engendrado pelo actor-candidato enovela Daisy no drama-em-gente pessoano, com fulcro em Álvaro de Campos. Enquanto testemunha biográfica e íntima da vida afectiva de Campos, Daisy dá largas à sua vocação de poética entertainer, divertindo didacticamente o público (com eventual «tratamento de choque» à mistura) através das revelações que faz sobre ele, acabando por confessar-se incapaz de rivalizar, no coração de Campos, com a memória do jovem malogrado Freddie - que fiz morrer soldado na Primeira Guerra Mundial, não sei se munido de «cigarreira breve» - que Álvaro muito amou, conforme os versos a ele consagrados em Passagem das Horas, citados na peça por uma amargurada Daisy. A vida e a obra do heterónimo nutrem-se mutuamente para construir o discurso de Daisy, como é disso exemplo um polémico diálogo entre ambos, que ela recorda, em torno do verso incompleto, «censurado» (na opinião da personagem de Daisy - idem: 41), omitido ou não lido (e fica-nos a dúvida face à origem das reticências no lugar da omissão), na $1 .^{\mathrm{a}}$ edição da poesia deste heterónimo (por João Gaspar Simões et al., em 1944, reiterada na edição da Nova Aguilar - Pessoa, 1981:270), com a expressão «paneleiro de Deus», pela qual Campos brinda Walt Whitman na longa Saudação poética que dirige a esse seu companheiro espiritual - ou a essa radical antítese de Pessoa, de acordo com a hermenêutica de Eduardo Lourenço, para quem sob a máscara da «falsamente frenética imaginação de Álvaro de Campos, Pessoa é a antítese de Whitman» (Lourenço, 1987: 151). Um verso que só apareceria transcrito na íntegra nas diferentes edições mais recentes da poesia de Campos («Rameira de todos os sistemas solares, paneleiro de Deus!»), como sejam as edições críticas de Cleonice Berardinelli (Pessoa, 1992: 73), de Teresa Rita Lopes (Pessoa, 1993: 139), ou na obra completa de Campos por Jerónimo Pizarro com Antonio Cardiello (Pessoa, 2019: 112).

Uma outra personagem inventada, trazida pela gravidade de uma Daisy contadora de histórias, é a da cantora negra albina Mary Burns, que me surgiu tanto da vivência do poeta enquanto jovem na então colónia britânica de Natal como pela presença notória de mulheres cantoras na poesia de Pessoa ortónimo, e de que existem exemplos musicados na 
peça (é o caso de «A lavadeira no tanque»). Mary Burns assinala o término do show de Daisy, depois de momentos hilariantes, musicais ou épico-dramáticos, como aquele em que uma Daisy xamânica incorpora o papel da grávida mãe de Pessoa, a conversar para o filho-poeta que gera, adivinhando-lhe os trilhos pretéritos e futuros, e também o medo de que ele herde a loucura da avó paterna; nesta única frase em que Daisy e Dionísia se reúnem num nó cénico, através da mãe de Fernando, que fala do sangue do seu feto como se fosse já também sangue seu.

MÃE DE F. P. [...] E eu tenho mais medo do sangue doido da avó Dionísia, que corre em nossas veias, do que das tuas extravagâncias de poeta escriturário [...]. (Rosa, 2002: 39)

Mas pouco restará para Daisy nos dizer, chegados à catarse do trágico, obtida através de um processo de narração dramática, isto é, após ouvirmos a história do assassinato induzido da cantora sul-africana Mary Burns, figura imaginada que o adolescente Fernando Pessoa teria ouvido cantar uma noite num bar de Durban, o Seaway to India, levado lá pelo padrasto. Vários níveis de leitura possível estão implicados nesta narração fabulística de uma história de amor com desfecho mortal, entre Mary e o francês branco Pierre du Lac, mercê de intolerâncias raciais e comportamentais, de fobia letal face à diferença. Muitos espectadores/leitores me testemunharam situar-se aqui o clímax dramático de Audição, uma peça que se serve, conforme já o expus no posfácio à peça, da descontinuidade lúdica de um music-hall entendido como criticismo da vida, segundo o formulou James Joyce (Rosa, 2013: 69) - e uma personalidade heteronímica que bem poderia contribuir com deambulações soltas acerca do cabaré e do music-hall é o desconcertante Jean Seul de Méluret, para quem Pessoa rascunhou em língua francesa esboços e embriões de ensaios, incluindo textos provocatórios e satíricos sobre exibicionismo e palco, identidades e comportamentos sexuais não normativos (Pessoa, 2006).

Ao narrar a fábula trágica da cantora negra albina que se entrega, como Ofélia, à morte por afogamento, «depois de lhe castrarem a voz e de lhe matarem o amante» (Rosa, 2002: 46), as palavras de Daisy revelam-se implacáveis na sua condensação energética, pois, como escreve Pessoa no texto em epígrafe, o drama é a máxima síntese possível do narrativo. O romance pode espraiar-se por centenas ou milhares de páginas escritas; o drama não, tendo em conta a sua destinação comunicacional última que é de natureza cénica. Se o regime de sentido da palavra na prosa romanesca é a extensão proliferante, já o regime de sentido da palavra na escrita do drama reside na intensidade e na concisão. E isto afigura-se-me válido mesmo para um texto como Audição - Com Daisy ao Vivo no Odre Marítimo, concebido sobremaneira por blocos verbais monologantes nos quais, ainda assim, procurei perseguir a intensa concisão como poética (em especial na segunda jornada da peça), isto é, a sensação da indispensabilidade do vocábulo, da frase, da expressão a ser dita; algo que se torna por inteiro visível para o dramaturgo quando a respectiva experimentação cénica tem lugar.

\section{CABARÉ DE OFÉLIA}

A tragédia de Mary Burns é um dos elos que ligam Audição à sua peça irmã Cabaré de Ofélia, eclodida do espaço do Odre Marítimo alguns anos depois, uma vez que, nesta segunda das minhas peças pessoanas, temos a dramatização do último show da cantora de blues no seu bar em Durban, e não somente a narração dele.

Foi Rui Pina Coelho quem um dia me questionou se a minha escolha do nome de Mary Burns teria algo que ver com a homónima companheira irlandesa de Friedrich Engels, sua proletária parceira de ideais e de vida. Trata-se de uma assinalável coincidência, pois a Mary Burns que invoco deve o seu nome à contracção onomástica daquela Mary com quem Campos lia versos do poeta escocês Robert Burns, em Passagem das Horas: «Mary, com quem eu lia Burns em dias tristes como sentir-se viver» (Pessoa, 2019: 144).

A geografia das canções escolhidas com poemas de Pessoa constitui uma organização partitural em paralelo aos textos, expondo o trilinguismo poético de Pessoa, no pressuposto que defendo e pratico da potencialidade de muita da sua poesia (em especial a ortónima) se mostrar vocacionada para o canto; e que concretizo desde 2012 como intérprete no projecto musical O Piano em Pessoa (Rosa \& Silva, 2018), em cujo repertório incluo composições com poemas seus que fiz para estas peças, incluindo os temas mais antigos que preexistiram em muito a escrita de ambas, como sejam as canções «Ma Blonde», «It really doesn't matter [D.T.]», ou «Há quanto tempo não canto». Não tenho notícia de que em Portugal tenha havido, antes destas peças irmãs no embarcadiço Odre Marítimo, quem houvesse musicado, fora da composição erudita, 


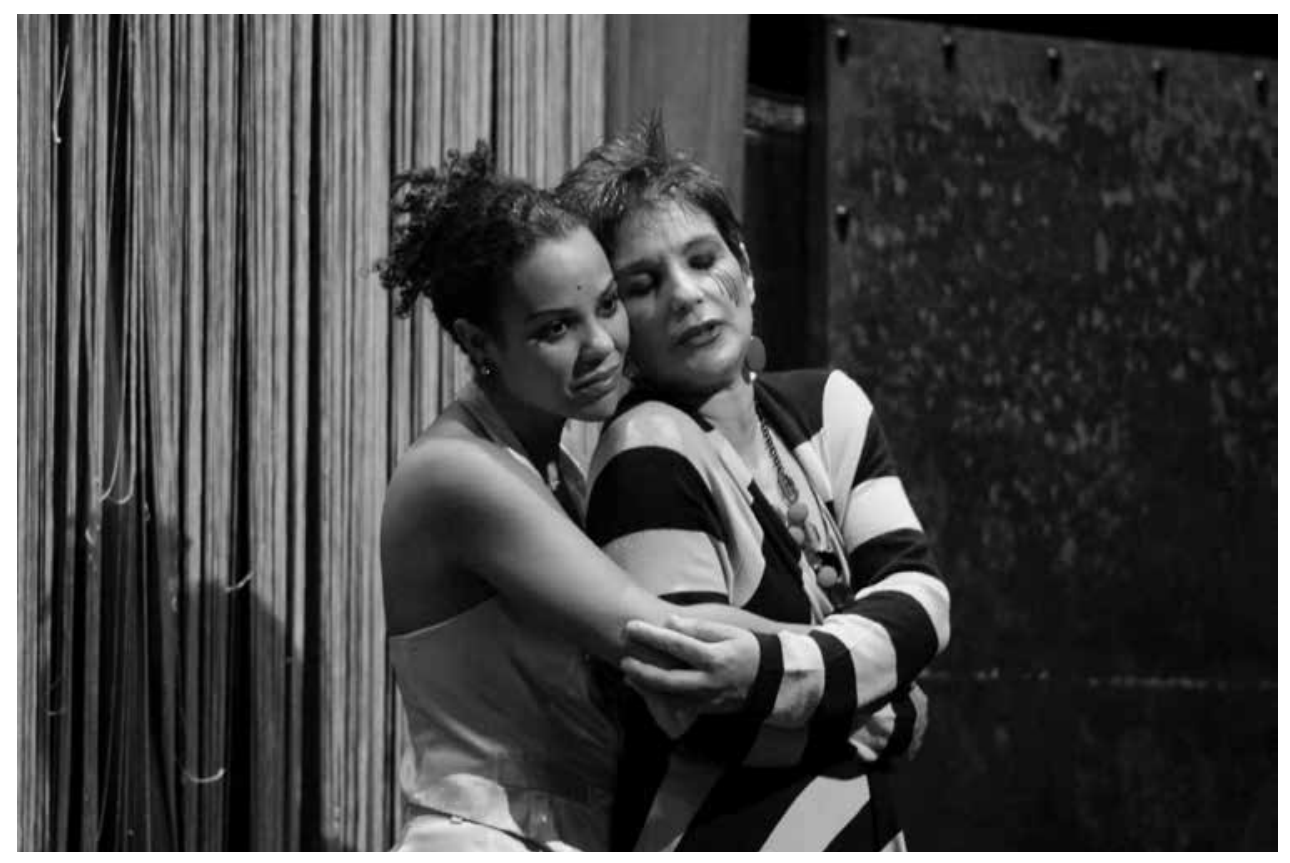

CABARÉ de OFÉlIA, de ARMANDO NASCIMENTO Rosa, ENC. CLAUDio HOCHMAN, CENDREV/TEATRO DA TRINDADE, 2007 (CATARINA MATOS E ROSÁRIO GONZAGA), [F] PEDRO SOARES

poemas escritos por Pessoa em inglês e em francês ou, pelo menos, que deles tivesse feito expressão pública. $\mathrm{E}$ se a recentíssima realidade (musical e editorial) a este respeito já começa a ser outra, o certo é que as razões para tão longo adiamento se devem fundamentar em argumentos como este que Jerónimo Pizarro discute, ao abordar os efeitos do uso demagógico sofrido pela célebre frase que Pessoa escreveu sob a identidade literária de Bernardo Soares:

Ora, a frase «Minha patria é a língua portugueza» [sic] não só tem sido descontextualizada e manipulada, por vezes com fins políticos, mas tem indirectamente facilitado o esquecimento das outras duas «pátrias» linguísticas de Fernando Pessoa: o inglês e o francês. Refiro-me, sobretudo, ao inglês, porque o francês terá sido, confessadamente uma «pátria» mais passageira [...]. (Pizarro, 2012:153)

Cabaré de Ofélia, escrita e estreada em 2007 (no Teatro Garcia de Resende, em Évora, encenada por Cláudio Hochman, com direcção musical de Ulf Ding, numa co-produção do Cendrev e do Teatro da Trindade, palco este onde se apresentou em Lisboa em 2008), publicada

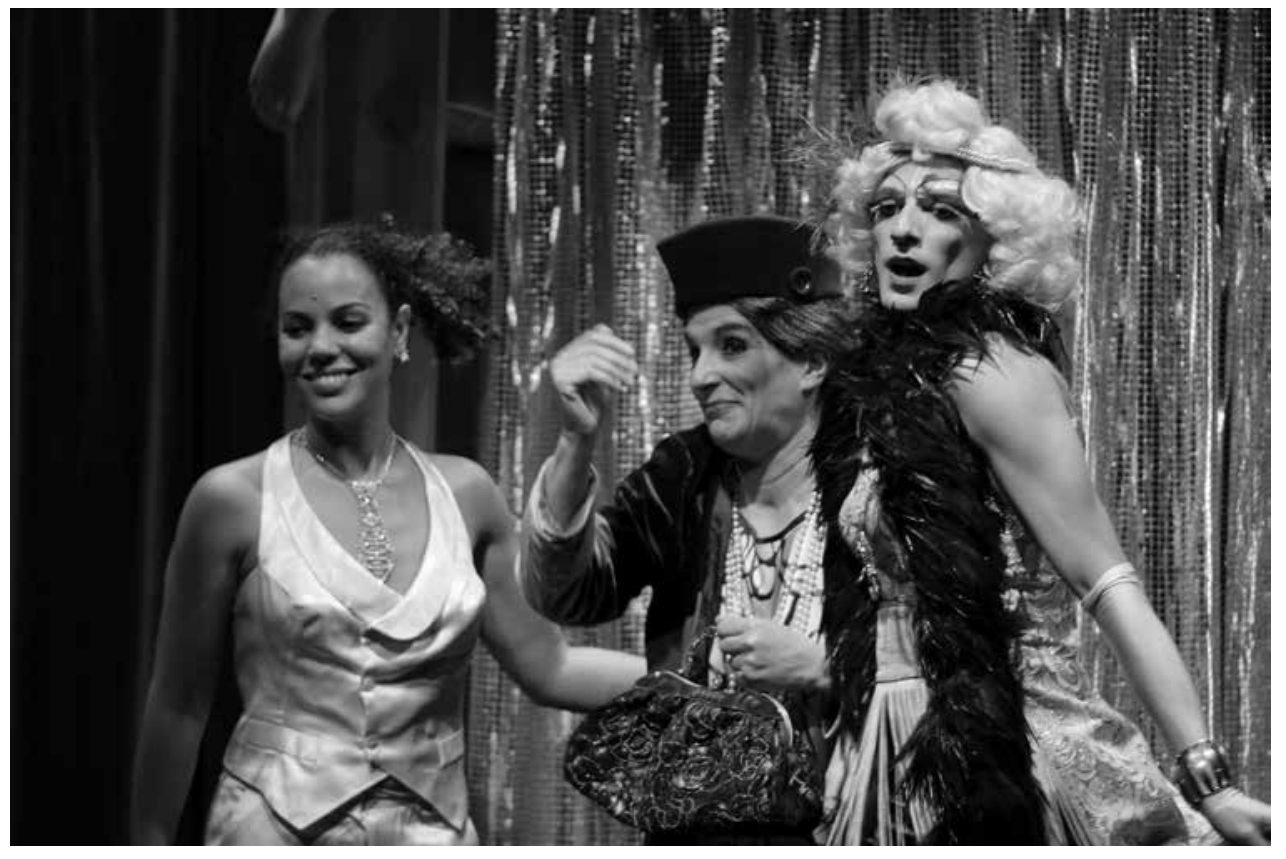

CABARÉ de OFÉlIA, DE ARMANDO NASCIMENTO ROSA, ENC. CLAUDiO HOCHMAN, CENDREV/TEATRO DA TRINDADE, 2007 (CATARINA MATOS, ROSÁRIO GONZAGA E HUGO SOVELAS), [F] PEDRO SOARES

em livro somente em 2013, no Brasil (numa edição conjunta com Audição), tal como o título indica, regressa ao lugar imaginário da segunda jornada de Audição; um Odre Marítimo agora pragmática e ironicamente consciente de estar em terra firme e não no mar, conforme o diz Daisy na apresentação inicial do show, porque não será fácil arranjar mecenas que patrocinem um navio assim, eminentemente teatral. Cabaré de Ofélia torna mais vigorosa e homogénea a sua natureza musical, mercê do diálogo constante mantido entre texto e canções numa peça para três intérpretes (e músicos ao vivo): duas actrizes e um actor travestido, na personagem que transita da peça anterior. Mas desta vez, Daisy aparece como a anfitriã do jogo dramático, visto o presente espectáculo ter por centro três outras personagens femininas, uma inventada, outra (que dá título enganosamente shakespeariano à peça) celebrizada graças a Pessoa, e a terceira convocada do então quase esquecimento da historiografia literária modernista: respectivamente, Cecília/Cecily, Ofélia Queiroz e Judith Teixeira (Viseu, 1880-Lisboa, 1959).

Segui de resto o rasto que abrira em Audição onde Daisy confessava a certa altura ter uma afilhada órfã chamada Cecily, arrancada também ela a «Soneto já Antigo» (ao menos o nome, dado que o parentesco entre 
ambas é ficção minha sobre a ficção poética de Pessoa): «essa estranha Cecily/ Que acreditava que eu seria grande...» (Pessoa, 1993: 69). Em Cabaré de Ofélia, Cecily revela-se afinal não ser simples afilhada, mas sim uma filha adoptiva de Daisy, originariamente chamada Cecília, menina brasileira da rua que Daisy decide adoptar quando em 1915 faz uma digressão ao Rio de Janeiro, para actuar no espaço lendário do Casino da Urca, divulgando então poemas dos seus amigos e insubmissos autores de Orpheu (segundo o conselho de conhecedor que me foi dado por António Mercado, dado que na versão primeira eu tinha forjado um nome de casa de espectáculos inexistente na cidade carioca: $o$ Chiquinha Gonzaga; mas ainda assim, a marca de ficção cronológica mantém-se porque o Casino da Urca, segundo me informou depois Patrícia da Silva Cardoso, parece só ter começado a funcionar no Rio como sala de espectáculos em data posterior a 1915).

Não obstante os modos diversos com que ambas as peças têm o seu arranque efabulador, também em Cabaré de Ofélia o motivo inicial deriva do show de uma actriz-cantora, de nome Lídia, mulata com nome pessoano, que apresenta o seu espectáculo de solo cabarético; abrindo com um monólogo onde ela descreve a discriminação racial de que foi alvo numa audição para uma companhia de teatro lisboeta, logo seguido pelo mais popular dos seus números, o de um strip-tease em trajes de freira, cantando em swing jazzístico a teologia blasfema e gnóstica de «Song of dirt», de Alexander Search. Mas Lídia irá rapidamente desdobrar-se em Cecily, personagem que foi a motivação primeira para esta peça, correspondendo ao desafio que me foi lançado pela actriz Catarina Matos, que dela seria intérprete na produção de estreia da peça, depois alternando o papel com Cheila de Lima, na parceria cénica com Hugo Sovelas (único actor que bisou Daisy, pois já a havia interpretado numa das encenações de Audição) e Rosário Gonzaga (Ofélia/Judith). O desdobramento de Lídia em Cecily é desencadeado graças à visita de uma espectadora idosa muito especial: Ofélia Queiroz, a namorada vitalícia de Fernando Pessoa. Ofélia persuade Lídia para que esta recrie Cecília, por achar que existem semelhanças flagrantes entre elas. Lídia irá corresponder a este repto, por intermédio de fotos e escritos pessoais de Cecily que Ofélia lhe confia para que a actriz possa invocar a personagem dessa mulher já desaparecida - a que o teatro dará, simultaneamente, vida cénica efémera no tempo do espectáculo e vida dramatúrgica perene e transformável no tempo cronológico.
Mas a Ofélia Queiroz que visitou esta peça mostra agora uma insuspeitada vocação de actriz (como se algo da natureza de poeta-actor do seu Fernando a contagiasse para os ritos a Dioniso), sendo ela a urdir um cenário dramático para poder trazer à vida do teatro a poetisa modernista Judith Teixeira, que Ofélia conheceu no passado e por quem sente saudades por andar tão olvidada. Desta forma, o título Cabaré de Ofélia não se traduz tanto pela presença e desenvolvimento da personagem de Ofélia Queiroz na cena, mas, em vez disso, porque é de facto Ofélia que provoca o processo dramático, como mestra oficiante da liturgia teatral, desejosa que está de fazer parte dela, ou seja, desse exercício libertador e catártico de ser outro; como se a memória da ascendência teatral do seu nome a levasse agora a substituir-se a um Hamlet morto e, no lugar de enlouquecer e se afundar nas águas, opta por ser a intérprete e a encenadora de uma persona histórica, culturalmente recalcada, que assinala a presença do outro como mulher em sujeito de discurso poético e dramático, e além do mais homoerótico, não sendo apenas musa distante e cerebralmente moldada pela invenção masculina. Judith Teixeira será por isso, na alquimia cénica da peça, a personificação possível e plausível dessa voz modernista que se exprime numa identidade de mulher concreta, eroticamente transgressora, que os homens revolucionários de Orpheu decidiram ignorar.

CECILY [...] A Judith era uma escritora irregular. Mas havia garra nalguns versos seus de burguesa decadente. (Entra Judith, e apresenta-se com os primeiros versos do seu poema «A Outra».)

JUDITH TEIXEIRA «A Outra, a tarada,/ aquela que vive em mim,/ que ninguém viu, nem conhece,/ e que enloirece/ à hora linda do poente/ pálida e desgrenhada $\rightarrow$

Eu sou sacerdotisa da beleza. Já fui grega e atlética. Hoje sou um pouco cheia de carnes, mas fico mais esbelta com o espetáculo de um corpo despido, que seja belo, ali a respirar na minha frente o hálito da vida. O Fernando Pessoa diz que o prazer de um corpo nu só existe para as raças vestidas. Mas eu não concordo. Acho que isso é preconceito dele. Então os índios do Brasil não apreciavam a nudez uns dos outros? [...] Pudesse eu ter sido o Pero Vaz de Caminha, travestido, e assim que chegasse à praia nas lusitanas naus, despia o meu traje salgado, e mostrava-me mulher para espanto dos marujos, e dançava nua com as índias e os índios no feitiço dos seus ritmos. Eu tenho alma de índia e corpo de bacante, e trago nas veias o calor dos trópicos, mas aqui faz muito frio e 
escrevo versos a sonhar com o Novo Mundo. Ó Europa velha com passado duvidoso! Eu sou a moça índia que tu não exterminaste. E quando eu morrer de velha como tu, mas bem velhinha, quero que me enterrem toda nua, nuazinha! (Daisy e Cecily batem palmas e gritam bravos ao discurso de Judith.)

CECILY A Judith era valente e gostava de escândalo. Depois de um divórcio penoso, arranjou um marido maternal e permissivo. Ela perdia a cabeça com as moças frescas como rosas. E claro, tinha um fraquinho por esta mulata. Mas eu nunca lhe dei esperanças. No dia da queima dos livros, lembro-me dela a pregar na praça junto às cinzas. Nunca a tinha visto assim. Com o orgulho amargo dos hereges. (Rosa, 2013a: 104-105)

Judith teria escrito uma peça de teatro, de nome Labareda, conforme o revela Eugénia Vasques, que procurou este manuscrito de paradeiro desconhecido, com resultados infrutíferos (Vasques, 2001: 90); e que a mais recente e alargada edição dos textos da autora também não logrou desvendar (Teixeira, 2015: 17). Na ausência de uma Labareda desaparecida, cria-se a peça para preencher esse vazio, a partir da história trágica da cantora negra albina de Durban, aqui contada em drama por outro ângulo e com outros intervenientes (como a prostituta Elsie, interpretada por Ofélia/Judith), e em que a própria Mary Burns surge na pele de Cecily no seu derradeiro show no Seaway to India, a que Fernando e o padrasto João Miguel Rosa assistem.

Cabaré de Ofélia interroga, num palco de cabaré poético (um género teatral muitas vezes depreciado como artisticamente menor e marginal, menosprezo esse que se presta ele mesmo a significativas leituras), o lugar da mulher como sujeito de um discurso literário, estético e existencial no modernismo português nascido sob o signo de Orfeu, o mítico fundador da poesia ocidental. Jogando com o homoerotismo inscrito na lenda órfica, numa paródia deliberada dos géneros, que inclui a desestabilização performativa das identidades sexuais, é como se perguntássemos: que é feito das Eurídices desse Orpheu, tendencialmente monossexual? E ao proceder a esta interrogação, forçoso se torna chamar à cena a personagem de Judith Teixeira, coeva e amiga que foi de Florbela Espanca, poeta bem maior do que ela - como a personagem de Judith o verbaliza na peça ao evocar a sua presença - e a quem fiz escrever um soneto apócrifo para ser cantado no espectáculo, em modo de chorinho, dedicado por Florbela à afrodescendente brasileira Cecília: «Bisneta de Chica da Silva».
Cabaré de Ofélia tematiza teatralmente esta rasura da mulher na explosão de Orpheu, procedendo a um resgate de Judith, bem como do que o seu olvido representa, através do poder da cena, para a qual não hesitei (conforme o excerto citado o prenuncia) em imaginar-lhe os versos que ela teria proferido na praça da capital onde lhe queimaram livros em Março de 1923, anos antes de a ditadura ser implantada; fogueira censória (promovida por estudantes de direita católica que incluía o jovem Marcello Caetano, aos quais é endereçado o «Aviso por causa da moral», pelo punho de Campos) onde arderam, além do seu livro de poemas Decadência, exemplares de Canções, de António Botto, e de Sodoma divinizada, de Raul Leal, obras ambas em edições custeadas por uma aventura sem retorno financeiro de um Fernando Pessoa editor, decerto análoga àquela na qual anos antes ele aplicara os dinheiros herdados de sua avó Dionísia.

\section{MENINO DE SUA AVÓ}

Antes de escrever Menino de sua Avó, em 2012, há cerca de sete anos já que eu desejava invocar na cena a doida avó paterna de Fernando Pessoa, essa avó Dionísia, cujo nome não poderia ser mais apelativo para o teatro lhe inventar uma sábia loucura comunicante, decerto bem diferente da demência progressiva em que ela foi mergulhando em vida, desde cedo, a atestar pelas notícias biográficas que se lhe referem. Desde que nasce, na casa do Largo de São Carlos, em Lisboa, Pessoa convive com a loucura da avó paterna, que em petiz o assusta, pois Dionísia já habita com o filho e com a nora ao tempo em que esta dá à luz o neto único (sobrevivo) de Dionísia Rosa Estrela Seabra. Ao regressar definitivamente da África do Sul, em Maio de 1907, Pessoa volta a viver com as tias-avós Maria e Rita e com a avó Dionísia (Zenith, 2008: 194) e, quando esta morre, quatro meses depois, há-de ele herdar o dinheiro com que lança a tipografia e editora Íbis, seu primeiro e malogrado investimento editorial. Ao falecer, Pessoa é sepultado no jazigo da avó, no Cemitério dos Prazeres; e ambos ficam a sós nessa última morada comum, como mo confirmou Richard Zenith, visto que os restos mortais de Joaquim de Seabra Pessoa, pai do poeta e filho de Dionísia, nunca para lá iriam. Avó e neto apenas serão separados na trasladação honorífica dos restos mortais deste para o claustro dos Jerónimos, nos 50 anos da sua morte, em 1985. O ciclo vital do berço à tumba é para Pessoa simbolicamente 
acompanhado por esta avó insana com o nome do deus do teatro declinado no feminino. Ambos tinham, por isso, de vir um dia à luz e à sombra da cena.

Mas, para que uma dupla deste peso se materialize, forçoso é que se verifique um horizonte de entusiasmo partilhado, capaz de dinamizar a empresa arriscada e exigente de reinventar Dionísia sob os desígnios do génio do seu neto poeta. Dionísia nasceu-me para a cena como se o seu nome helénico bebesse da fonte imaginante do mesmo drama-em-gente que Pessoa criou, no seu metateatro de poetas. E tal só foi possível porque contei com uma cúmplice e interlocutora muito especial a quem o nascimento desta peça se deve, bem como a produção cénica que a estreou, em Abril de 2013, no Teatro A Barraca/Cinearte (espectáculo que cumpriu uma centésima apresentação em Outubro de 2019, no Centro Cultural Olga Cadaval, em Sintra, após muitas digressões pelo país e três viagens ao Brasil, na última das quais foi distinguido com o Prémio Especial do Júri na Festa Internacional de Teatro de Angra dos Reis/Rio de Janeiro, em 2014).

Felicitava eu Maria do Céu Guerra pela sua criação cénica no espectáculo D. Maria, a louca, com texto do autor brasileiro Antônio Cunha, confidenciei-lhe haver uma outra louca sobre a qual um dia gostaria de escrever: Dionísia Seabra, a avó de Pessoa. De imediato, Maria do Céu fez uma careta para mimar o rosto que se vê nas fotos com a pessoana avó anciã, na casa da Rua da Bela Vista, à Lapa.

- Já temos a personagem! - disse eu.

- E essa peça será para mim! - disse a Céu, desafiadora, desfazendo a careta.

- Mas primeiro terei de a escrever - respondi.

O pacto ficou então selado, suspeitando eu que o actor e então meu aluno de mestrado Adérito Lopes, que contracenava oculto e mudo no disfarce de escrava negra da rainha louca em terras do Brasil, viria a ser o intérprete do neto poeta - e acerca deste seu trabalho de actor em busca de Pessoa, redigiria Adérito uma tese de doutoramento (Lopes, 2018). Menino de sua Avó presta-se simultaneamente a um jogo evocativo para com um outro espectáculo pessoano mais antigo de Maria do Céu Guerra, O menino de sua mãe, com textos vários de Pessoa, apresentado primeiramente no Teatro São Luiz, em Lisboa, e depois no antigo espaço do Politeama (onde a ele então assisti), em 1988-1989, e no qual a actriz e encenadora interpretava em estreia absoluta «A Carta da Corcunda para o Serralheiro», texto espantoso e inteiramente desconhe-

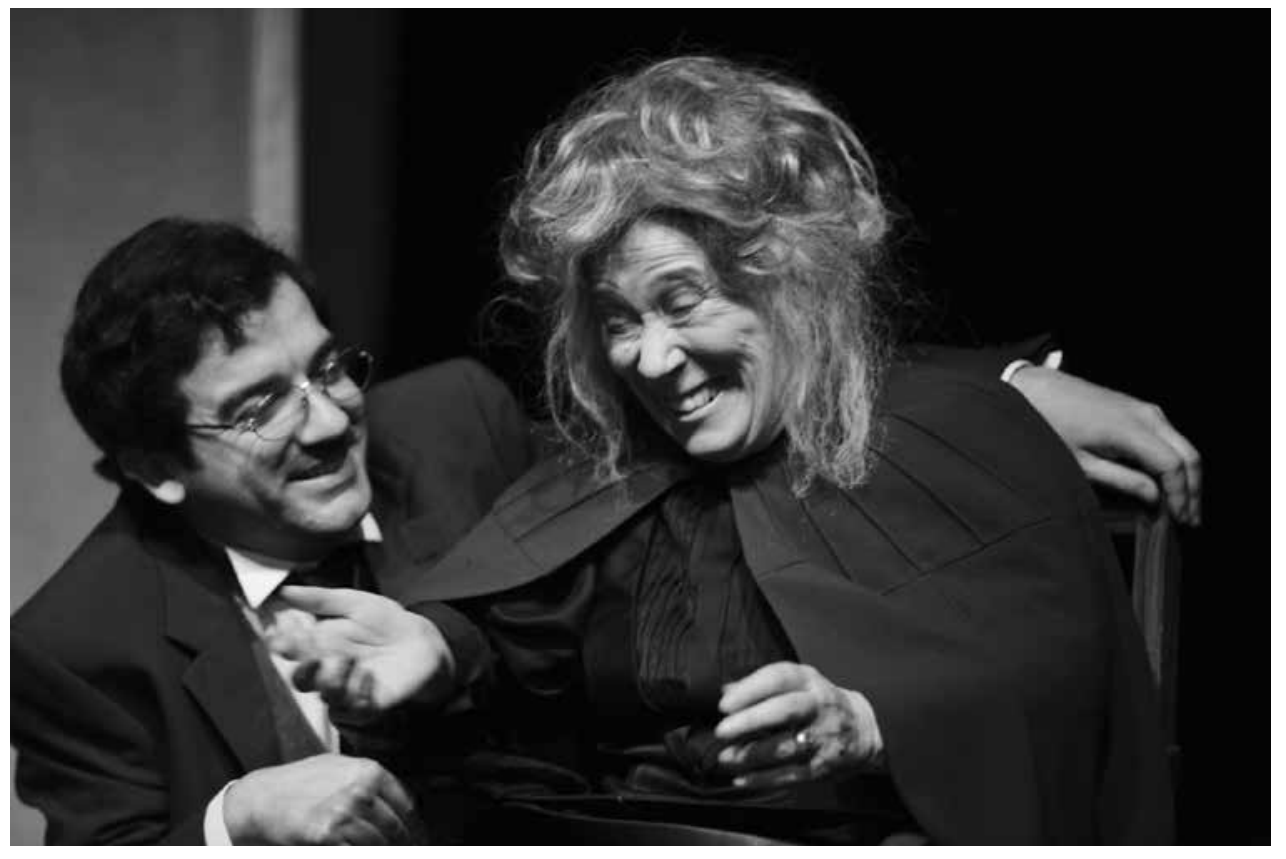

MENINO DE SUA AVó, DE ARMANDO NASCIMENTO ROSA, ENC. MARIA DO CÉU GUERRA, A BARRACA (ADÉRITO LOPES E MARIA DO CÉU GUERRA), TEATRO A BARRACA/CINEARTE (2013), [F] PEDRO SOARES

cido até então; breve e singular obra-prima dramatúrgica, revelado pela investigação de Teresa Rita Lopes, que o publicaria pouco depois (Lopes, 1990). Por tudo isto, e porque o dactiloscrito com a carta assinada por Maria José, a única mulher heteronímica com obra literária que Pessoa criou, não se encontrava então datado - já a edição do texto por Pizarro e Ferrari avança a data de 1929-1930 para este dactiloscrito (Pessoa, 2013: 626) -, quis que avó e neto brincassem na peça, por antecipação, com essa ficção que ele escreverá no futuro; inspirada de facto numa mulher que debruçava o seu olhar numa janela dessa Rua Coelho da Rocha, onde ele tem residência a partir de 1920. A maturidade de escrita evidenciada em «A Carta da Corcunda para o Serralheiro» denuncia haver sido composta por um Pessoa com muito mais idade do que os vinte anos que ele tem ao tempo do seu primeiro encontro com o fantasma metateatral da avó defunta, que se faz passar por mãe de Maria José, numa partida teatral que prega a Fernando.

A peça consiste num dueto cénico distribuído por sete encontros entre avó e neto, ocorridos num arco temporal que tem início em 1907, em que ambos coabitam na casa da Lapa, até ao momento em que o espectáculo se estreia, em 2013, no Portugal sob os efeitos da troika, 
refém da crise financeira. Nos dois primeiros encontros, estão ambos ainda vivos, e se, no primeiro deles, Dionísia se encontra na iminência de mais um internamento em Rilhafoles, a que resiste em vão sem que Fernando possa interceder por ela junto das tias, no segundo encontro, ela já se encontra internada no hospício e recebe a visita do neto, que servirá de involuntário agente para Dionísia se evadir de lá, e assim ela possa realizar o desejo de vir falecer a sua casa. Uma evasão que é também a viagem mítica para um outro limiar, além da vida, além da morte, onde avó e neto coabitarão na busca por uma ucronia através do fármaco cénico. São por isso dois encontros de intensa cumplicidade, entre um jovem tímido e visionário e uma anciã que padece de lúcida demência, atravessados por humor e drama, ternura e compaixão, num registo de «realismo poético», conforme Maria do Céu Guerra o caracterizou (no esplêndido prefácio à edição em livro da peça), que «nos vai apresentando um conflito de família, paixão entre uma avó meia louca e o seu neto poeta, Fernando Pessoa, que transporta a irrealidade de um heterónimo [...]» (in Rosa, 2013b: 8-9).

Um heterónimo ou pré-heterónimo, ou personalidade literária, conforme as designações propostas pelos estudiosos, Alexander Search é uma criação pessoana de juventude onde, pela umbilicalidade de datas, é impossível não supor um impacto do convívio com Dionísia em versos seus, de rebelião existencial e ontológica, que transparecem o confronto com a loucura, com os excluídos, com aqueles que escapam ao chamado mundo da instável normalidade; e no qual se manifesta esse foco de inquietação que foi para Pessoa, desde cedo, a aliança temível mas desafiadora entre a perturbação mental e a criação de génio - temática para a qual Jerónimo Pizarro tem dado um contributo ímpar, tanto na edição crítica dos textos de Pessoa sobre génio e loucura, como no volume de comentário analítico que os acompanha (Pizarro, 2007) e que quis o jogo dos acasos eu ter degustado somente já depois de ter a peça concluída.

NETO Foi bom ter vindo de férias a Portugal, há cinco anos. Estava mais crescido. Comecei a compreender melhor o seu modo de ser.

Avó O meu modo de ser louca, neto, que se agrava com a idade.

NETO $O$ génio e a loucura são irmãos siameses. Estou cada vez mais convencido disso. Há sempre um órgão que os liga entre si, um laço de sangue e de palavras.

AVó Então se assim é, também podem ter outro parentesco.

NETO E qual seria?
AVó $O$ de avó e neto. Eu sou a loucura e tu és o génio.

NETO Obrigado, avó. Mas eu ainda não fiz obra que mereça esse título. AVó Mas já a começaste, Fernando, já a começaste. Os teus versos em inglês não sou capaz de ler. Mas são o anúncio de poetas maiores que tu vais dar à luz. (Rosa, 2013b: 26-27)

Se numa primeira versão da peça todos os sete encontros tinham uma extensão semelhante entre si, o incentivo de Céu Guerra levou-me a que ampliasse os dois primeiros, conduzindo a que a soma de ambos adquirisse uma duração análoga à reunião dos restantes cinco, o que exigiu um intervalo a separá-los, tornando o espectáculo a haver numa proposta bipartida; dois espectáculos em um só, ao ponto da primeira parte (constituída pelo primeiro e segundo encontros) poder ser apresentada de forma autónoma, como já aconteceu na reposição de 2019 - e nesse caso, comporta o subtítulo A jornada em vida. Esta ampliação a que procedi permitiu uma respiração dramática ao convívio entre Dionísia e Fernando, em especial o relevo concedido a Alexander Search. Em primeiro lugar, pela efabulação que invento para uma génese visionária de Search em alto-mar, na viagem funérea de navio que Fernando fez de Durban para Lisboa, com a mãe, com o padrasto e com o cadáver da irmãzita Madalena, episódio contado à avó no qual se prenuncia a interrogação metafísica e gnóstica que há-de acompanhar a vasta e múltipla odisseia pessoana, expressa, por exemplo, em frases como estas que coloco no seu discurso: «[s]omos todos cativos de um deus-cadáver»; «[é] em vida que os vermes nos devoram»; «a morte é esta vida que vivemos!» (idem: 29). Em segundo lugar, esta ampliação possibilita o único momento mais notório de presença textual explícita de Pessoa, dentro do guião da peça, constituído por dois poemas de Search, a partir da tradução portuguesa de Luísa Freire, que Dionísia lê de viva voz num recital breve dirigido aos asilados como ela, entre os quais o público se vê ironicamente incluído, no pátio suposto do hospital psiquiátrico, que viria a adquirir o nome do seu então director clínico, Miguel Bombarda.

Liberta da verossimilhança realista inicial, a segunda parte da peça empreende uma jornada cénica, surreal e mediúnica, fragmentada no tempo e no espaço, em cinco encontros, plenos de metateatralidade, que nos permitem acompanhar avó e neto após a morte física. Em termos de concepção teatral, se a primeira parte se pauta pelo drama dionisíaco de raiz aristotélica, com a empatia e a catarse emocional que o define, o regime de mimese da segunda parte da peça não é Dioniso que invoca, 


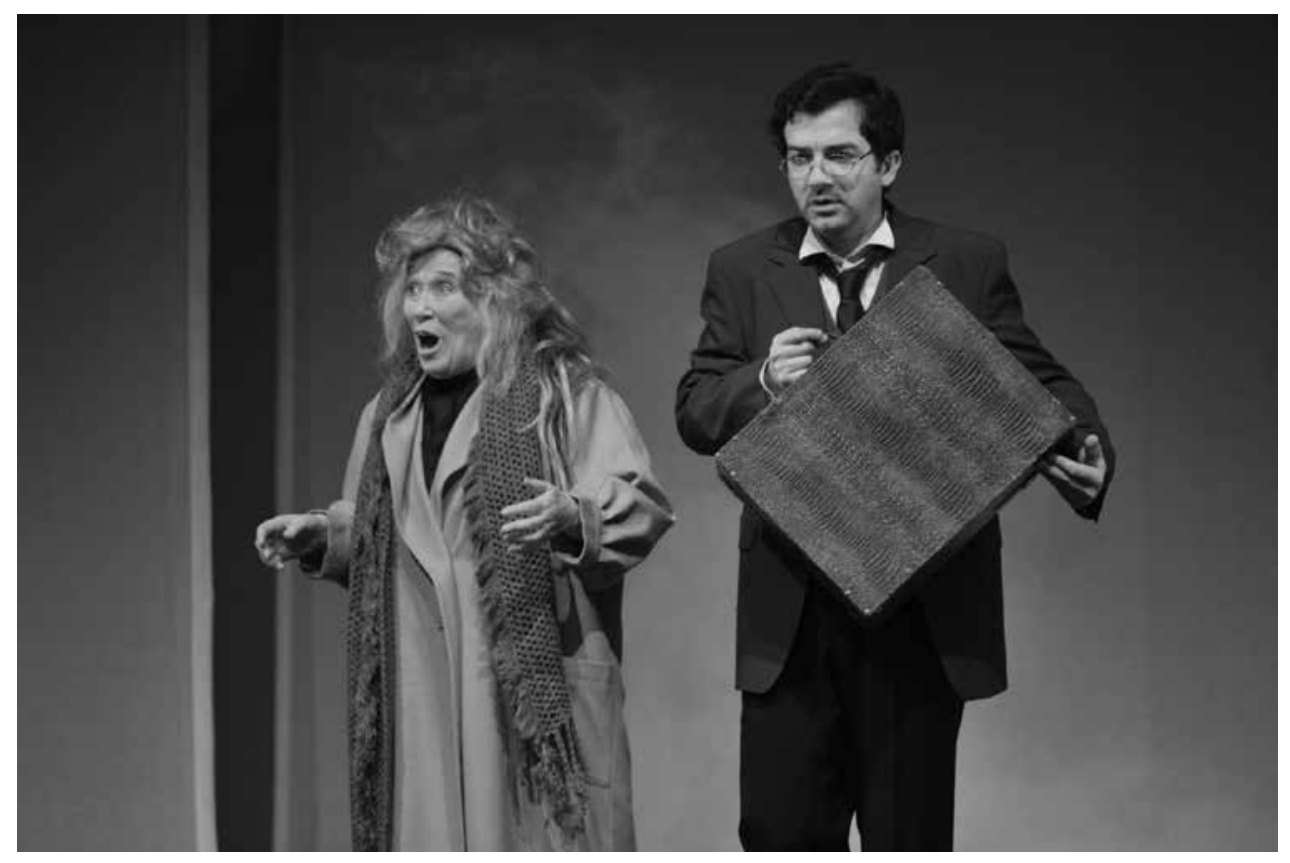

MENINO de SUA AVó, DE ARMANDO NASCIMENTO ROSA, ENC. MARIA do CÉU GUERRA, A BARRACA (MARIA DO CÉU GUERRA E ADÉRITO LOPES), TEATRO A BARRACA/CINEARTE (2013), [F] PEDRO SOARES

mas, fazendo uso de uma análise mitocrítica, é antes tutelado por Hermes, deus alado e decifrador, mensageiro entre os vivos e os mortos. Não obstante ter uma Dionísia actriz a habitá-lo, o elemento hermesíaco (Rosa, 2012: 132-135) prepondera sobre o dionisíaco na segunda parte da peça, porque Dionísia ganhou uma outra natureza além da vida corpórea, e Fernando irá seguir-lhe os passos. No terceiro e quarto encontros, Fernando está ainda vivo e é a avó que o visita na condição de fantasma expedito. Após a morte, Dionísia fica curada da loucura e ganha o prazer e a aptidão do teatro. Ela própria o diz ao neto: «[a] Dr. a Morte é mais experiente do que o Dr. Júlio de Matos» (Rosa, 2013b: 59). Não mais paciente do mal psíquico que a tolhia em vida, ela conquistou o controlo de si mesma e experiencia a lúdica condição de actriz. Ambos partilham o jogo jubiloso de ser outros e se, no terceiro encontro, Dionísia se finge passar pela mãe da corcunda Maria José, já no quarto encontro, vinte anos decorridos, é uma máscara de Pessoa que a recebe no escritório da Baixa onde trabalha, sob o disfarce do astrólogo Rafael Baldaia, relutante que está o neto em lhe aparecer, melindrado pela ausência tão prolongada da avó, que em vão o tentou contactar do lado de lá por duas décadas; mas a insistência de Dionísia fá-lo-á deixar cair a máscara, para surgir uma outra de pavor abissal, na verbalização de uma queda da psique no vazio, que é um dos meus momentos textuais favoritos no que a peça procura fazer jus à ontologia trágica de Pessoa:

AVó Ora neto, as máscaras são invenções tuas.

NETO Elas protegem-me do perigo de mim mesmo.

AVÓ De que perigo te proteges tu, Fernando?

NETO Um perigo parecido com o seu. O perigo do abismo. Olho-me no espelho e vejo apenas um estranho absoluto. Desconheço aquele que me olha e a imagem apavora-me. Procuro em mim esse eu que sente medo, mas nada encontro onde agarrar-me. Só um vazio sem fim, a queda interminável. Sou a falha na falésia e o meu corpo o manequim absurdo que arrancaram do armazém da loja e foi lançado do alto dos rochedos para se estilhaçar em plástico oco no fundo do desfiladeiro. A minha vida, avó, consiste nessa queda. $O$ boneco que sou fica preso às arestas das rochas e desfaço-me em pedaços. Não quero continuar a dor da queda, mas não posso evitar a velocidade alucinante.

AVó Não estás louco ainda, neto, porque extrais poesia do teu padecimento.

(Rosa, 2013b: 71-72)

O quinto encontro terá lugar em 1935, com Fernando acabado de transpor o limiar da morte, no Hospital de São Luís dos Franceses, num episódio que comporta um divertimento cénico, ao modo de rito de passagem, em que ambos parodiam as veladoras d'O Marinheiro. Embora Dionísia desempenhe o papel de Hermes psicopompo que o acolhe na morte, o tempo histórico e sociocrítico dos vivos continua a ser espelhado pelas suas conversas. Achando-o a avó muito envelhecido para a idade com que a morte o visita, Fernando responde-lhe numa frase: «É o Estado Novo que me tem feito velho» (idem: 72). A partir daí, a peça conta com os dois na condição fantasmática, mas o jogo do teatro será sempre a forma de ambos enganarem a tirania e o vácuo do tempo. No sexto encontro, já com avó e neto a residirem no jazigo dos Prazeres, Dionísia representa o papel de uma sénior Ofélia Queiroz (que ainda era viva à data de 1985), a visitar o túmulo do seu defunto namorado, num exercício de «teatro de investigação», como lhe chamará Fernando; cena exigente que a avó preparou - e em cujo desfecho poemático se fundem as loucuras de Dioniso, Dionísia e da Ofélia hamletiana - para tornar inesquecível a sua despedida no momento em que subtraem o 
neto à sua companhia, por via da trasladação. No sétimo e último encontro, Dionísia visita Fernando nos Jerónimos, aparecendo-lhe este disfarçado de Luiz de Camões num sketch de comédia, brincando com a ansiedade da influência que provocara um espadachim literário e épico entre Pessoa e Camões, no qual tomamos também conhecimento de «uma conspiração de poetas mortos» que pretende «mexer com a diplomacia mundial ao mais alto nível [...] para debater o naufrágio português e europeu». (idem: 92)

Como criação cénica em que a vida insubmissa do teatro se substitui ao silêncio imaterial da morte, a peça termina numa resolução a que chamaria urobórica, ou seja, com as personagens de Fernando e Dionísia a sentarem-se na sala para assistir ao desempenho de si mesmas no início do espectáculo que acabaram de nos apresentar.

Menino de sua Avó confere continuidade a este herético e fantasmático ofício de nigromância teatral que caracteriza grande parte da dramaturgia que compus até hoje. É sintomático que o termo me surgira inicialmente a tutelar o longo ensaio doutoral que consagrei ao teatro escrito de António Patrício, mas a designação de Máscaras nigromantes que para ele destinei (Rosa, 2003) também a vejo aplicável a muito do teatro que imagino e concretizo na forma textual, enquanto dramaturgo. Contemplamo-nos inevitavelmente no gesto de perscrutar os outros; o teatro sabe-o desde sempre. O nigromante conjurava os mortos, para deles obter adivinhação e clarividência em benefício dos vivos. E o teatro é o lugar onde o corpo, a voz, a psique dos actores se dedicam a materializar a ficção onde vivos e mortos se indistinguem no gesto criativo de os «fingir tão completamente»; para que os espectadores experienciem em si mesmos a surpresa apaixonante e memorável que o colectivo dos fazedores da cena lhes reserva, em cada espectáculo renovada.

\section{$\left[\mathrm{BNP} / \mathrm{E}_{3}, 14^{1}-2 \mathrm{O}^{\mathrm{r}}\right]$}

A litteratura dramatica ${ }^{1}$ é uma subspecie da litteratura narrativa, e esta uma especie do genero litteratura.

1 <Uma peça de theatro $\mid$ A litteratura dramatica

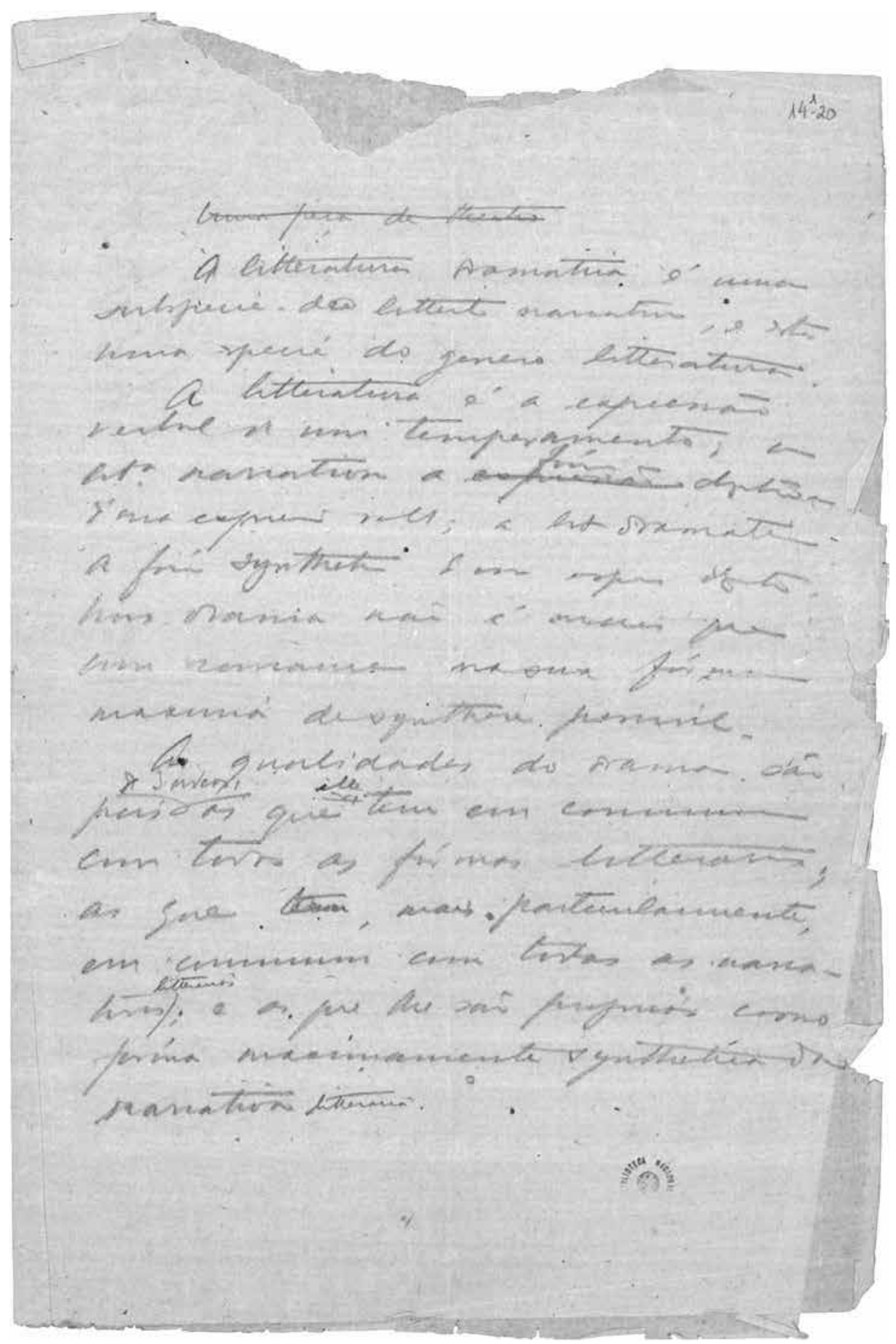

[BNP/E3, 141-20 E 20AR] UM BIFÓLIO IRREGULAR MANUSCRITO A LÁPIS. TEXTO PARCIALMENTE TRANSCRITO E PUBLICADO POR MARIA ALIETE GALHOZ. TALVEZ SEJA DOS INÍCIOS DA DÉCADA DE 1920. TRANSCRIC̣ÃO REVISTA POR PAULY ELLEN BOTHE E JERÓNIMO PIZARRO. 
A litteratura é a expressão verbal de um temperamento; a lit[teratur]a narrativa a fórma ${ }^{2}$ objectiva d'essa expressão verbal; a lit[teratura] dramatica a fórma synthetica d'essa expressão objectiva. Um drama não é mais que um romance na sua fórma maxima de synthese possivel.

As qualidades do drama são pois de 3 ordens: as que elle tem ${ }^{3} \mathrm{em}$ commum com todas as fórmas litterarias; as que tem, mais particularmente, em commum com todas as narrativas litterarias ${ }^{4}$; as que lhe são proprias como fórma maximamente synthetica da narrativa litteraria.

\section{$\left[\mathrm{BNP} / \mathrm{E}_{3}, 14^{1}-2 \mathrm{O}^{\mathrm{ar}}\right]$}

Será um drama tanto mais perfeito quanto maior fôr seu valor a dentro de todas ${ }^{5}$ estas qualidades. Como litteratura, será tanto maior o seu valor quanto maior puder ser a expressão ${ }^{6}$ verbal de um temperamento.

Porisso nenhuma especie de drama eguala o drama em verso; como, porém, ninguém falla em verso, é forçoso que, para poder ser em verso sem quebra de objectividade, o drama em verso se occupe de assumptos que nos não ficam por dictos fora da prosa. Restam pois ao drama em verso, de um lado, os assumptos remotos ou no tempo ou no genero, e, de outro lado, os que propositadamente tratados como remotos em um ${ }^{7}$ proposito de farça. O que não é *necessário é que o drama em verso *discorra ${ }^{*}$ longas ${ }^{*}$ analyses - ou como a $3 .{ }^{a}$ visão de Hamlet.
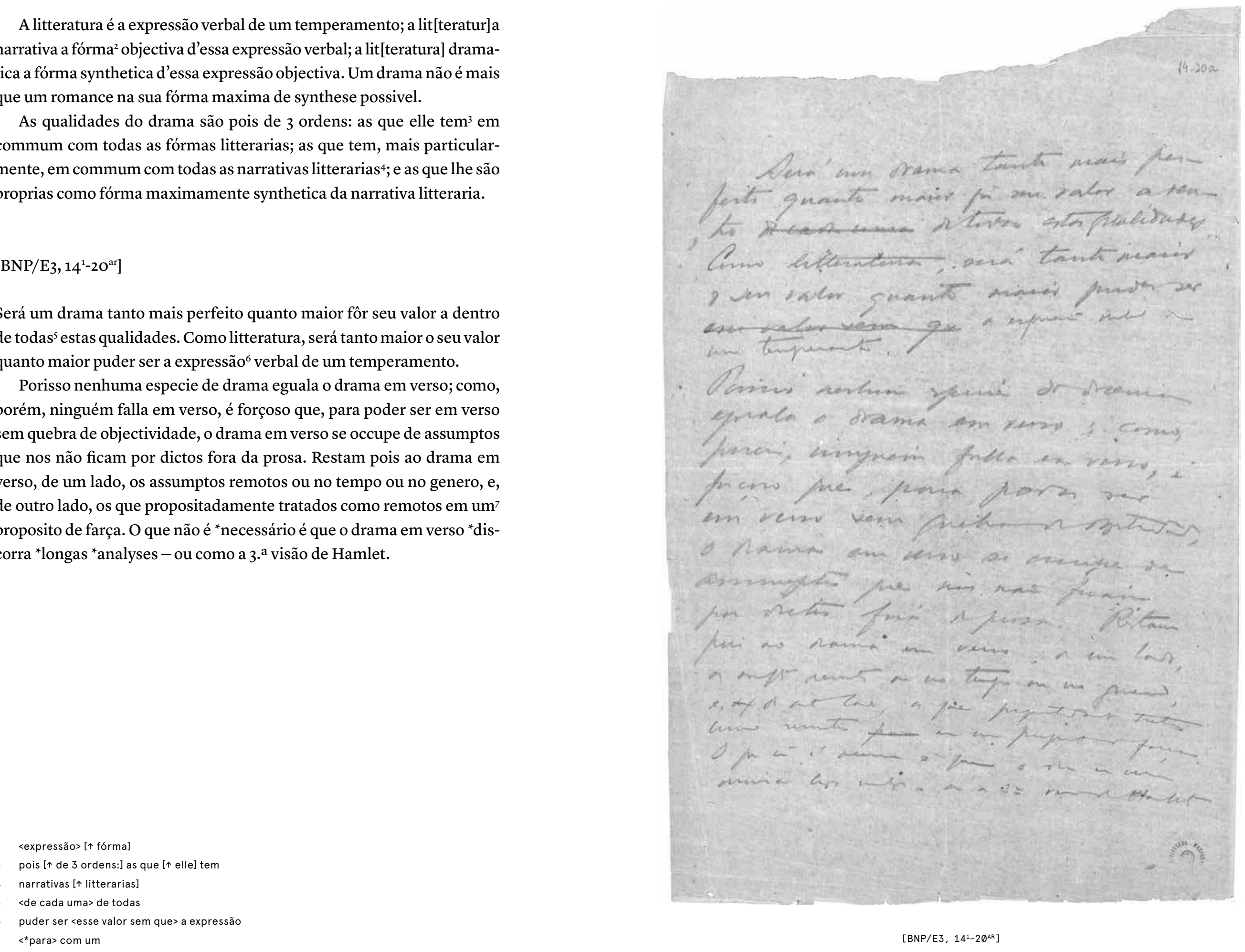

$\left[B N P / E 3,14^{1}-20^{A R}\right]$ 


\section{REFERÊNCIAS BIBLIOGRÁFICAS}

BLоом, Harold (1997), The Anxiety of Influence: A Theory of Poetry, 2.a ed., Nova Iorque e Oxford, Oxford University Press.

CORREIA, Natália (1958), Poesia de Arte e Realismo Poético, Lisboa, edição da autora.

JACKson, K. David (2010), Adverse Genres in Fernando Pessoa, Nova Iorque e Oxford, Oxford University Press.

Lopes, Adérito (2018), Uma interpretação de Pessoa: Manual de um Ator-a partir de Menino de sua Avó, de Armando Nascimento Rosa, criação de Maria do Céu Guerra e Adérito Lopes, tese de doutoramento em Comunicação, Cultura e Artes, Faro, Universidade do Algarve.

LOPES, Teresa Rita (2004), Fernando Pessoa et le drame symboliste. Héritage et création, 2.a edição, Paris, Éditions de la Différence.

- (1990), Pessoa por Conhecer. Textos para um novo mapa, vol. 2, Lisboa, Editorial Estampa.

LOUREnç o, Eduardo (1987), Tempo e Poesia, Lisboa, Relógio D'Água.

PESSOA, Fernando (2019), Obra Completa de Álvaro de Campos, edição de Jerónimo Pizarro e Antonio Cardiello, Lisboa, Tinta-da-china.

- (2013), Eu sou uma Antologia. 136 autores fictícios, edição de Jerónimo Pizarro e Patrício Ferrari, Lisboa, Tinta-da-china.

- (2006), Obras de Jean Seul de Méluret, edição de Rita Patrício e Jerónimo Pizarro, Edição Crítica de Fernando Pessoa, Série Maior, vol. vIII, Lisboa, Imprensa Nacional-Casa da Moeda.

- (1999), Alexander Search. Poesia, edição e tradução de Luísa Freire, Lisboa, Assírio \& Alvim.

- (1993), Álvaro de Campos, Livro de Versos, edição crítica de Teresa Rita Lopes, Lisboa, Editorial Estampa.

- (1992), Poemas de Álvaro de Campos, edição crítica de Cleonice Berardinelli, Edição Crítica de Fernando Pessoa, Série Menor, Lisboa, Imprensa Nacional-Casa da Moeda.

- (1981), Obra Poética, edição de Maria Aliete Galhoz, Rio de Janeiro, Nova Aguilar.

PIZARRo, Jerónimo (2017), «Pessoa qua Campos: existencia dialógica», in Christina Johanna Bischoff/Till Kinzel/ /Jarmilla Mildorf (eds.), Das Dialoggedicht/Dialogue Poems. Studien zur deutschen, englischen und romanischen Lyrik/Studies in German, English and Romance Language Poetry, Heidelberga, Universitätsverlag, pp. $477-492$.

- (2012), Pessoa existe?, Lisboa, Babel.

- (2007), Fernando Pessoa: Entre Génio e Loucura, Edição Crítica das Obras de Fernando Pessoa, Estudos, vol. III, Lisboa, Imprensa Nacional-Casa da Moeda.

ROSA, Armando Nascimento (2013a), 2 Dramas com Daisy ao vivo no Odre Marítimo, São Paulo, Escrituras Editora. - (2013b), Menino de sua Avó, prefácio de Maria do Céu Guerra, Lisboa, Redil Publicações.

- (2012), «Um Édipo - O drama ocultado. Mitodrama fantasmático em um acto», in Três Peças Mitocríticas, vol. 1, 2. a edição, prefácio de Marvin Carlson, Coimbra, Imprensa da Universidade de Coimbra.

- (2003), As Máscaras Nigromantes. Uma leitura do teatro escrito de António Patrício, Lisboa, Assírio \& Alvim.

- (2002), Audição-com Daisy ao vivo no Odre Marítimo, Évora, Casa do Sul.

Rosa, Nascimento, e SILVA, António Neves da (2018), O Piano em Pessoa, CD áudio e livreto, Lisboa, Tradisom/ /IPL/Casa Fernando Pessoa.

TEIXEIrA, Judith (2015), Poesia e Prosa, edição de Cláudia Pazos Alonso e Fabio Mario da Silva, Lisboa, Publicações Dom Quixote.

VASQUEs, Eugénia (2001), Mulheres Que Escreveram Teatro no Século XX em Portugal, Lisboa, Colibri.

woLFF, Charlotte (1986), Magnus Hirschfeld. A Portrait of a Pioneer in Sexology, Londres, Quartet Books.

ZENITH, Richard (2008), Fernando Pessoa. Fotobiografias Século XX, Lisboa, Casais de Mem Martins, Rio de Mouro, Círculo de Leitores.

\section{BREVE HISTORIAL CÉNICO DAS TRÊS PEÇAS}

Audição - Com Daisy ao vivo no Odre Marítimo estreou-se em Lisboa em 2003 (14/2-9/3) no Teatro Municipal Maria Matos, numa produção da Cassefaz com encenação de Élvio Camacho, cenografia de Bruno Guerra, figurinos de Marco Geraldes, interpretações de Jorge Andrade, Inês Nogueira e do pianista Filipe Raposo, que fez a direcção musical; com uma digressão a Évora, ao Teatro Garcia de Resende (3/5/2003). Ocorreram quatro outras produções cénicas: pelo TEF - Companhia de Teatro do Funchal, em 2004 (23/3-30/3), no Teatro Baltazar Dias, com encenação de Eduardo Luiz e interpretações de Élvio Camacho, Hugo Castro Andrade e António Plácido, entre outros; pelo Teatro Estúdio Fontenova, de Setúbal, estreado em 2004 (1/9) e reposições até 2010, com encenação de José Maria Dias, interpretações de Eduardo Dias e Bruno Moraes, com digressões a palcos de Lisboa, incluindo o Café-Teatro da Comuna (11-19/3/2005), o Auditório da Casa Fernando Pessoa (12/6/2010), e a Sala Azul do Teatro Aberto como espectáculo convidado do II Congresso Internacional Fernando Pessoa (27/11/2010); pela Propositário Azul, no Espaço do Tempo, em Montemor-o-Novo, em 2004 (1-4/10), com encenação e versão dramatúrgica de Eduardo Condorcet, cenografia e figurinos de Sara Machado da Graça, interpretações de Hugo Sovelas, Anabela Ferreira e trio de jazz dirigido por Ulf Ding, com digressões a Lisboa (Teatro da Comuna; 10-20/11/2004), Évora (a bruxa Teatro; 28/11/2004), Coimbra (Teatrão; 10-13/10/2005), e Porto (Teatro Helena Sá e Costa; 28-29/1/2005); e, em 2008, uma produção escolar teve lugar no Conservatório/Escola das Artes do Funchal, num projecto do aluno Filipe Luz, com direcção cénica de Kot-Kotecki, que fez digressão ao Porto (14/7/2008) ao Festival SET - Semana das Escolas de Teatro.

Cabaré de Ofélia estreou-se em Évora no Salão Nobre do Teatro Garcia de Resende, em 2007 (28/11-8/12), numa co-produção entre o Cendrev (Centro Dramático de Évora) e o Teatro da Trindade, em cujo palco da sala principal se apresentou em Lisboa, em 2008 (20-31/5), com encenação de Claudio Hochman, cenário e figurinos de Sara Machado da Graça, desenho de luz de João Carlos Marques, interpretações de Hugo Sovelas, Rosário Gonzaga e Catarina Matos ou Cheila de Lima, e os músicos João Bastos, Luís Cardoso e Ulf Ding, que fez a direcção musical. Em 2014, uma segunda produção da peça, pelo Teatro do Marimbondo, ocorreu em Lisboa, na Casa Raphael Baldaya (14/10-15/12), encenação e versão 
dramatúrgica de José Henrique Neto que também interpretou em parceria com Paula Só, Cheila de Lima e o teclista Marco P. Rodrigues.

Menino de sua Avó estreou em Lisboa no Teatro A Barraca/Cinearte, em 10/4/2013, numa criação cénica dirigida por Maria do Céu Guerra, que interpretou em parceria com Adérito Lopes, cenário e figurinos de José Costa Reis, música original de António Victorino d'Almeida, iluminação de Fernando Belo e vídeo de Paulo Vargues; espectáculo com longa carreira cénica entre 2013 e 4/10/2019, incluindo treze digressões por palcos de todo o país, de Bragança a Loulé, e três viagens ao Brasil: ao Teatro Dulcina, no Rio de Janeiro (3-5/5/2013), como espectáculo teatral de encerramento das Comemorações do Ano de Portugal no Brasil; na reabertura cénica do Teatro Popular Oscar Niemeyer, em Niterói/Rio de Janeiro, 26-27/10/2013; e como espectáculo convidado d'A FITA - Festa Internacional de Teatro de Angra dos Reis (23/11/2014), onde foi distinguido com o Prémio Especial do Júri. O texto da peça integra desde 2016 o Plano Nacional de Leitura. Na tradução inglesa de Susannah Finzi, Fernando and his Grandmother, a peça teve uma leitura encenada em Londres em 31/7/2019, no Omnibus Theatre, sob a direcção de Almiro Andrade, com interpretações de Dora DaCruz e Patrick Campbell, no âmbito do Out of the Wings Festival, de Dramaturgia Ibero-Americana, promovido pelo King's College.

\section{ARMANDO NASCIMENTO ROSA}

Dramaturgo, ensaísta e criador musical, doutorado em Estudos Portugueses, mestre em Estudos Literários Comparados e licenciado em Filosofia pela Faculdade de Ciências Sociais e Humanas da Universidade Nova de Lisboa, é autor de 23 livros de dramaturgia e/ou ensaio e dois álbuns de música. É professor na Escola Superior de Teatro e Cinema do Instituto Politécnico de Lisboa desde 1998, onde coordena a área de Teorias e Estéticas, e membro do CIAC - Centro de Investigação em Artes e Comunicação. 